\title{
Karakter Musikal Lagu Gedé Kepesindenan Karawitan Sunda
}

\author{
Endah Irawan ${ }^{1}$ \\ Sekolah Tinggi Seni Indonesia (STSI) Bandung \\ R.M. Soedarsono, dan G.R. Lono L. Simatupang \\ Sekolah Pascasarjana, Universitas Gadjah Mada Yogyakarta
}

\begin{abstract}
ABSTRAK
Penelitian ini difokuskan pada tiga hal yaitu: (1) menemukan ciri-ciri musikal lagu gedé; (2) menunjukkan perbedaan relasi musikal antara lagu gedé dengan pertunjukan wayang golék dan kiliningan; dan (3) menunjukkan kompleksitas hubungan garap di dalam lagu gedé, yaitu hubungan antara nyanyian sindén dengan nyanyian alok, rebaban, gambangan, dan kendangan. Penelitian ini menggunakan pendekatan etnomusikologis didasarkan pada cara kerja ala Wim van Zanten, yaitu memadukan aspek musikologis dan antropologis. Musik ditempatkan sebagai objek utama sekaligus dasar relasinya dengan persoalan-persoalan kebudayaan dan masyarakat. Hasil penelitian ini menunjukkan bahwa lagu gedé menunjukkan peran, proses, interaksi dan kompleksitas garapnya khusus. Pada sisi pencipta lagu, lagu gedé diakui sebagai pengguritan yang sulit dan langka. Pada sisi penyaji, membawakan lagu gedé diperlukan persyaratan seperti: modal vokal bagus, menguasai perbendaharaan lagu dan laras, terampil menafsir garap lagu dan memberi sénggol-sénggol unik. Dengan ketiadaan lagu gedé, mutu garap kesenimanan sinden dan pangrawit dan jalinan interaksi kemampuan musikal di antara pemeran garap vokal, rébab, gambang, dan kéndang mengalami keterbatasan.
\end{abstract}

Kata kunci: lagu gedé, kepesinden, karakter musikal

\begin{abstract}
The Musical Characters of Lagu Gedé Kepesindenan on Sundanese Karawitan. The research is mainly focused on the three things: (1) to find the musical characteristics of lagu gedé; (2) to show the difference on the musical relationship of lagu gede' song with a puppet show and kiliningan; (3) to show the complexity of the working relationship on lagu gede, such as the relationship between the singing of Sinden and the hymns of alok, rebaban, gambangan, and kendangan. The ethno musicological approach of lagu gede is based on the work method of Wim van Zanten which is a musical approach with an anthropological perspective. The two aspects - musicological and anthropological - are respectively combined. Music is intensively placed as the main object in order to discover the basis of its relation with cultural and social issues. The results of the research on lagu gedé show the role, process, interaction, and complexity of the musical interpretation which are characterized by a slow tempo. From the composer's point of view or the musical composition, lagu gedé is recognized as a difficult and rare form of pengguritan. From the performers' point of view (the sinden or female vocalist and the pangrawit or musician), a number of special skills are required in performing lagu gedé. These may include a good voice, a good command of the musical repertoire, tuning, and musical composition, and the ability to interpret the music and provide the unique sénggol-sénggol as well. By the absence of lagu gedé, there will be more limited quality of interpretation and artistry of the sinden and pangrawit, and the musical skills and interaction among the musicians (such as the vocalist, rébab, gambang, and kéndang players).
\end{abstract}

Keywords: Lagu gedé, kepesinden, musical characters

\section{Pendahuluan}

Bagi orang awam, bisa jadi lagu gedé merupakan sesuatu yang asing dan hampa makna, tetapi bagi orang yang terlatih dengan musik (karawitan), lagu gedé dapat digunakan sebagai satu petunjuk

1 Alamat korespondensi: Jurusan Karawitan, Sekolah Tinggi Seni Indonesia (STSI) Bandung. Jln. Buah Batu, Bandung. HP. 081321865038.E-mail: eirbagus@gmail.com 
di antara jenis-jenis karawitan Sunda lain untuk memahami karawitan Sunda. Lagu gedé dikenal sebagai satu jenis lagu dalam karawitan Sunda. Lagu ini kerap disamakan atau disebut dengan sebutan lain sebagai lagu buhun, lagu gamelan, sekar ageung, lagu ageung, atau lagu klasik.

Lagu gedé memiliki bentuk dan struktur karawitan tersendiri yang berbeda dengan bentuk dan struktur jenis karawitan Sunda yang lain. Garap penyajian lagunya pun memiliki kekhususan, demikian pula dengan peran, interaksi dan kompleksitas garapnya.

Keberadaan lagu gedé pada karawitan Sunda pernah mengalami masa keemasan bersamaan dengan popularitas kesenian wayang golék dan kiliningan sekitar tahun 1950-an sampai dengan dekade tahun 1980-an. Namun, seiring hadir dan berkembangnya seni Sunda populer lain seperti: kesenian Jaipongan, degung kreasi, dan pop Sunda, keberadaan lagu gedé terpinggirkan.

Bagi seniman, akademisi, dan apresian yang terlatih, kreativitas garap lagu gedé dalam karawitan Sunda merupakan barometer untuk menilai kualitas kesenimanan sindén dan wiyaga (pemain gamelan). Kecerdasan, kecakapan, dan keterampilan musikalitas seniman dapat diamati dan dinilai dari kemampuan mereka menggarap lagu ini, apakah seniman tersebut tergolong seniman mahir atau tidak. Sindén yang membawakan lagu gedé diperlukan persyaratan-persyaratan seperti: memiliki vokal bagus, menguasai perbendaharaan

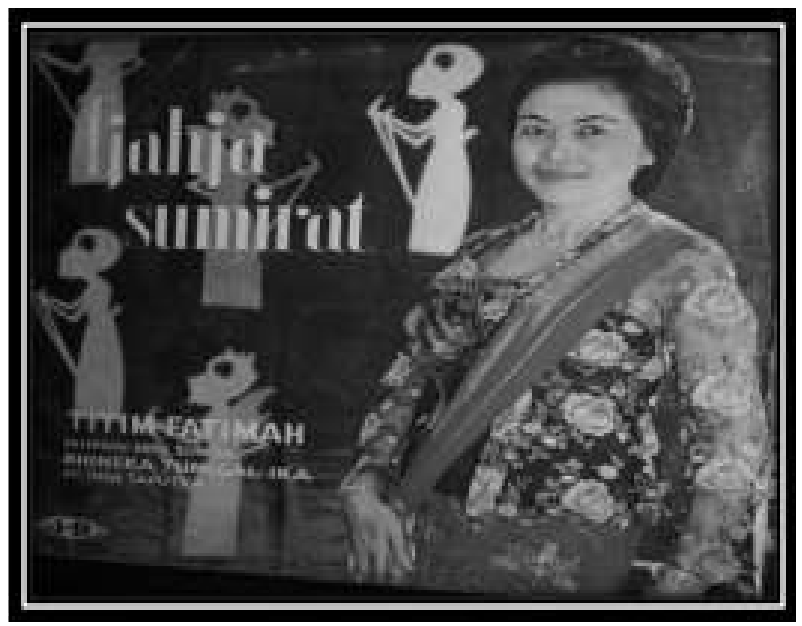

Gambar 1. Cover kaset Gamelan Seni Sunda Cahya Sumirat, Produksi J \& B Record. Pesindén: Titim Fatimah, Lagu gedé Cahya Sumirat (Gambar koleksi: Endah Irawan) lagu, laras, gending, memiliki tafsir garap lagu, dan memberi senggol-senggol unik, karena lagu gedé banyak memberikan peluang mengolah rasa musikal. Titim Fatimah dan Upit Sarimanah termasuk sinden yang popular di masyarakat dengan memiliki gaya tersendiri (sénggol).

Di lingkungan pendidikan seni, lagu gedé masih diajarkan kepada siswa atau pun mahasiswa Jurusan Karawitan. Bahkan, lagu ini masih digunakan sebagai sumber untuk ujian penyajian dan penciptaan karya S1 dan S2 di STSI Bandung, ISI Surakarta, dan ISI Yogyakarta.

Kini lagu gedé hadir dan bertahan hanya pada beberapa pertunjukan wayang golék. Hanya beberapa dalang saja seperti Cecep Supriyadi, Dede Amung Sutarya, dan Asep Sunandar, yang masih mempertahankan lagu gedé dalam pertunjukannya. Dunia kreatif pengguritan (pembuatan/penciptaan) lagu gedé diakui oleh sebagian penggurit lagu sebagai sebuah dunia pengguritan yang sulit dan langka. Selain dianggap sulit, alasan lain adalah lagu ini dianggap tidak diminati oleh selera pasar industri musik.

Lagu gedé yang dianggap 'membosankan' ternyata terbantahkan oleh kreativitas seniman. Beberapa album kaset popular sekarang menggunakan sumber lagu gedé sebagai kreativitas, antara lain: Karatagan Namin (bajidoran), Bambung Hideung (pop Sunda), Tonggeret (pop Sunda), Album kaset berjudul Ceu Nyai jeung kacapina (jaipongan), lagu Entog Mulang (konterporer kelompok Zitermania), dan yang lainnya. Lagu gedé pun dijadikan dasar kreativitas "Parade Sinden" yang disponsori UNPAD Bandung dan Pemda Kabupaten Subang.

\section{Karakter Musikal Lagu Gedé Kepesindenan}

Penelitian atas ciri musikal lagu gedé dipengaruhi oleh estetika mengurai musik yang dikembangkan oleh Roger Scrutton (2009: 20). Scrutton mengurai musik dari unsur yang paling hakiki yaitu bunyi. Ia memberikan landasan atas musik sebagai organisasi musikal dan makna musikal. Menurutnya, nada, ritme, melodi, dan harmoni bukan sekedar bentuk-bentuk organisasi musikal, tetapi merupakan pengalaman musikal yang paling utama di dalam kebudayaan. 
Adapun makna musikal dapat ditemukan dengan menghubungkan unsur-unsur bunyi, nada, ritme, melodi, harmoni, tonalitas, bentuk, isi, nilai, analisa, ekspresi, pertunjukan, hingga kebudayaan.

Karakter musikal merupakan fenomena musikal yang terelasi dari sebuah permainan melodi, ritme, dan dinamika yang tergarap, terstruktur, dan terpola dengan kiat, model, dan gaya tertentu sehingga menghasilkan rasa tertentu pula (Ardana, 2013: 143). Ciri musikal dapat juga dilihat dari struktur musiknya. Apabila diterapkan dengan konsep-konsep yang terdapat di dalam karawitan Sunda, karakter musikal dan sekaligus keunggulan musikal lagu gedé tidak dapat diragukan. Kompleksitas musik termuat di dalam struktur musikal lagu dan tersusun dari unsurunsur musik serta sastra yang menyatu. Unsurunsur musik dimaksud meliputi: nada, laras, surupan, wilet, pola kenongan dan goongan, wirahma beserta prinsip naékeun-nurunkeun, juga hubungan garap di antara sindén, alok, rebab, gambang, dan kendang, atau dalang. Adapun sastra yang dimaksud adalah stilisasi bahasa dengan mempertimbangkan aspek syair yang murwakanti (persajakan bunyi), rineka wacana (diksi), rinéka sastra (gaya bahasa), dan pakeman basa (idiom). Adapun keunggulankeunggulan musikal lagu gedé sebagai berikut.

\section{Nada}

Nada memiliki peranan sangat penting dalam lagu Sunda khususnya lagu gedé kepesindénan sebagai elemen musikal dari teks lagu. Sebuah teks lagu terbentuk melalui pengetahuan dan penggunaan nada. Hal yang menjadi pertanyaan apa jadinya bila lagu gedé, tidak bernada ? Mungkin yang akan terdengar adalah susunan bunyi yang asing, tidak beraturan, dan tidak biasa bagi pendengaran orang Sunda, khususnya para pelaku atau penikmat lagu gedé (kawih kepesindénan) tradisi Sunda. Ciri khusus nada sebagai bunyi yang teratur ukuran dan penempatannya. Selain itu, pemilihan nada dengan mempertimbangkan interval dan tinggi rendahnya menjadikan teks lagu memiliki arti musikal. Berdasarkan pengetahuan nada dan tata-nada inilah lagu gedé kawih kepesindénan dapat tercipta sebagai lagu tradisi yang sampai sekarang masih dikenal dan diminati oleh para seniman tradisi, khususnya dalam pertunjukan kiliningan, wayang golék, jaipongan, serta karya baru pop Sunda.

Penulisan notasi angka karawitan Sunda setelah era Machyar Angga Koesoemadinata dan Jaap Kunst, berkembang tidak lagi 5 nada atau 7 nada, tetapi mencantumkan nada-nada tengahan yang lain, seperti 1- (baca: di), 2+ (baca: meu), 4+ (baca: teu). Hal ini dikemukakan oleh Rustandi Mulyana bahwa penggunaan tiga nada: 1- (di), 2+ (meu), dan 4+ (teu), dapat dicermati pada lagu Karang Nunggal yang ditranskripsi oleh Djudju Sain Martadinata pada bagian embat sawilet dan dua wilet laras Madenda dengan surupan 4 = T, 2 = G. Hal sejenis dapat pula dicermati pada beberapa lagu kawih wanda anyar Mang Koko dengan tanskripsi notasi, seperti pada lagu Angkrék Djapati di Tjibodas, dan lagu Apan Ieu Kuring (Rustandi Mulyana, 2005: 149). Namun yang penulis cermati pada kawih kepesindénan lagu gedé irama lalamba dan irama lenyepan, tidak ditemukan nada 1- (baca: di) dan nada $2+$ (baca: meu), tetapi yang umum digunakan adalah nada 3- (dibaca: ni), 5+ (dibaca: leu), 4+ (dibaca: teu). Adapun lagu gedé irama lalamba dan irama lenyepan yang menggunakan ketiga nada tengahan 5+ (leu), 4+ (teu), dan 3(ni)) madenda dan degung tersebut, antara lain: Kawitan, Banjar Sari, Udan Mas, Sedih Prihatin, dan lagu Balaganjur. Kemudian lagu gedé yang hanya menggunakan 2 nada (5+ dan 3-, atau 4+ dan 3-), antara lain: lagu Banjar Mati, Géhgér Soré, Gorompol, Sungsang, Kulu-kulu Bem, Pangrawit, Rénggong Doblang, Sriwedari, dan Tablo. Adapun lagu gedé yang menggunakan satu nada tengahan, yaitu hanya pada lagu yang berlaras pélog jawar, digunakan nada 3- (ni), antara lain: lagu Barong, Bayeman, dan Sétrasari (Juju Sain, 1977).

Sampai sekarang beberapa nama nada ini masih dikenal dan digunakan oleh sebagian seniman karawitan Sunda, khususnya seniman kiliningan dan wayang golék terutama di lingkungan seniman yang tidak terpengaruh pendidikan seni formal. Pengistilahan nada-nada ini digunakan dalam pembelajaran dan pertunjukan, penggunaan nama-nama nada, tanpa mempertimbangkan interval antar nada, lebih umum digunakan oleh seniman ini adalah: singgul, galimer, panelu, kenong (loloran), barang (tugu), liwung (bungur), dan sorog. 


\begin{tabular}{lcclcc}
\hline \multicolumn{2}{l}{ Jaap Kunst } & \multicolumn{5}{l}{ SMKI/STSI } \\
Nada & Damina & Angka & Nada & Damina & Angka \\
\hline Singgul & $\mathrm{La}$ & 5 & Singgul & $\mathrm{La}$ & 5 \\
Galimer & $\mathrm{Ti}$ & 4 & Galimer & $\mathrm{Ti}$ & 4 \\
Panelu & $\mathrm{Na}$ & 3 & Panelu & $\mathrm{Na}$ & 3 \\
Panangis & $\mathrm{Meu}$ & $2+$ & - & - & - \\
Liwung & $\mathrm{Ni}$ & $3-$ & Liwung & $\mathrm{Ni}$ & $3-$ \\
Kenong & $\mathrm{Mi}$ & 2 & Loloran & $\mathrm{Mi}$ & 2 \\
Barang & $\mathrm{Da}$ & 1 & Tugu & $\mathrm{Da}$ & 1 \\
Sorog & Leu & $5+$ & Sorog & Sorog & $5+$ \\
Pamiring & $\mathrm{Di}$ & $1-$ & - & - & - \\
\hline
\end{tabular}

Tabel 1. Nama Nada pada Lagu Gedé Kepesindénan dalam Sistem Damina

Dalam lingkungan pendidikan karawitan (SMKI/STSI) di Bandung, penyebutan nama nada singgul, galimer, panelu, kenong (loloran), barang (tugu), liwung (bungur), dan sorog, menyebutnya nada mutlak, artinya nada tetap tidak berubah khususnya yang terdapat dalam instrumen gamelan. Sedangkan penamaan nada yang ditulis dalam notasi damina dengan angka 1 (da), 2 (mi), 3 (ni), 3 (na), 4 (ti), 5+ (leu), 5 (la), menyebutnya nada relatif, artinya nada yang dapat berubah apabila surupan nada dasarnya ditempatkan pada nada mutlak yang lain (pindah surupan). Nadanada tersebut bila disepadankan dengan sistem Daminatila (Tabel 1).

\section{Laras dan Surupan}

Laras dan surupan dalam lagu gedé merupakan persyaratan yang harus dikuasai bagi seorang sindén, alok, dan pemain rebab. Laras menjadi kerangka acuan sekaligus bingkai untuk menafsirkan sistem nada yang melekat atau relevan dengan lagu, gending atau pun iringan lagunya.

Penguasaan surupan sangat menentukan kemampuan seorang vokalis (sinden dan alok) dan pemain rebab dalam membangun dan menguatkan rasa musikal terhadap lagu yang dibawakan serta dijalin bersama, sesuai dengan gending atau instrumen pengiring lainnya. Gaya ungkap nyanyi-an pribadi sindén dan atau alok, maupun gaya ungkap rebaban pengrebab menjadi nampak dengan me- ngolah surupan secara kreatif dan cermat. Artinya, surupan maupun laras menjadi alat atau teknik untuk mengungkapkan ekspresi musikalitasnya.

Hasil identifikasi laras terhadap 52 lagu gedé kepesindénan, terdapat empat jenis laras yaitu laras saléndro, pélog, madenda, dan degung. Keempat jenis laras dimaksud dapat disajikan secara mandiri satu laras maupun dalam cara penggabungan dua atau tiga laras. Ada 13 lagu laras saléndro: lagu Béndra, Gunung Sari, Kastawa, Kawitan, Puspawarna, Kagémbang, Paksi Tuwung, Papalayon Solo, Rénggong Bandung; 12 lagu laras pélog: Bayeman, Gagak Sétra, Karawitan, Kéndo, Sétra Sari, Karanginan, Kuwung-kuwung, Parujakan, Rénggong Buyut, Rénggong Doblang, dan Sulanjana; 11 lagu laras madenda: lagu Balaganjur, Banjar Jumut, Banjar Sari, Banjar Sinom, Cahya Sumirat, Jalantir, Pangrawit, Papalayon Ciamis, Sedih Prihatin, dan Udan Mas; 1 lagu laras degung: lagu Kulu-Kulu Bem; 3 lagu gabungan laras saléndro dan madenda: lagu Gorompol, Géhgér Soré, dan Sungsang; 4 lagu gabungan laras madenda dan degung: lagu Banjar Malati, Panghudang Rasa,Sriwedari, dan Tablo; 1 lagu gabungan laras saléndro, madenda dan degung: lagu Tablo Kasmaran (Tabel 2).

\section{Embat}

Embat dapat juga berarti wilet, yaitu penentuan ukuran waktu tentang cepat lambatnya perjalanan musikal atau periode struktural yang berdasarkan aksentuasi melodi, yang diletakkan pada bagian garapan melodi dan ditandai dengan nada pancer, kenong, dan gong.

Penggunaan embat dalam lagu gedé terbagi dalam dua pola irama lagu, yaitu lenyepan dan lalamba. Embat lagu gedé irama lenyepan umumnya adalah embat opat (4) wilet. Dalam irama lalamba terdiri dari beberapa pola embat, antara lain: lima (5) wilet, genep (6) wilet, dalapan (8) wilet, dan sapuluh (10) wilet. Praktik penyajian embat lalamba ini ada dua pola. Pertama, penggunaan satu bentuk embat. Kedua, penggunaan bentuk embat perpaduan dua bentuk wilet dan atau tiga bentuk wilet.

Hasil identifikasi embat lagu gedé menunjukan bahwa lagu gedé bentuk embat 4 wilet: Balaganjur, Banjar Jumut, Banjar Sari, Banjar Sinom, Cahya Sumirat, Jalantir, Kagémbang, Karang Ngambang, 


\begin{tabular}{|c|c|c|c|c|c|}
\hline No. & Judul Lagu & Peran & Baris Lagu & Laras & Surupan \\
\hline \multirow[t]{4}{*}{1.} & Banjar & Alok & $1,6-7,20-21$ & Degung & $2=T$ \\
\hline & Malati & Sindén & $2-5$ & Degung & $2=\mathrm{T}$ \\
\hline & & & $8-10,18-19$ & Madenda & $4=T$ \\
\hline & & & $11-17$ & & $3=T$ \\
\hline \multirow[t]{2}{*}{2.} & Barong & Sindén & $1-6,9-11,13-22$ & Pélog jawar & $1=\mathrm{T}$ \\
\hline & & Alok & $7-8,12,23-24$ & Pélog jawar & $1=\mathrm{T}$ \\
\hline 3. & Bayeman & Sindén & $1-20$ & Pélog jawar & $1=\mathrm{T}$ \\
\hline \multirow{2}{*}{\multicolumn{2}{|c|}{ 4. Béndra }} & Alok & $1-2,8-9,12-13$ & Saléndro & $1=\mathrm{T}$ \\
\hline & & Sindén & $3-7,10-11,14-15$ & Saléndro & $1=\mathrm{T}$ \\
\hline \multirow{2}{*}{\multicolumn{2}{|c|}{ 5. Gagak Sétra }} & Alok & $1-4$ & Pélog jawar & $1=\mathrm{T}$ \\
\hline & & Sindén & $5-16$ & Pélog jawar & $1=\mathrm{T}$ \\
\hline \multirow[t]{4}{*}{6.} & Géhgér Soré & Sindén & $1-6,17-23$ & Madenda & $4=T$ \\
\hline & & & $15-16$ & Madenda & $4=P$ \\
\hline & & & $31-36$ & Saléndro & $1=\mathrm{T}$ \\
\hline & & Alok & $7-14,24-30$ & Madenda & $4=T$ \\
\hline \multirow{7}{*}{\multicolumn{2}{|c|}{ 7. Gorompol }} & Alok & $1-4$ & Saléndro & $1=\mathrm{T}$ \\
\hline & & & $13-15$ & Madenda & $4=P$ \\
\hline & & & 16 & Madenda & $4=T$ \\
\hline & & Sindén & $5-12$ & Saléndro & $1=\mathrm{T}$ \\
\hline & & & $7-19$ & Madenda & $4=P$ \\
\hline & & & $20-23$ & Madenda & $4=S$ \\
\hline & & & 24 & Madenda & $4=T$ \\
\hline \multirow{2}{*}{\multicolumn{2}{|c|}{ 8. Gunung Sari }} & Alok & $1-2,9-10$ & Saléndro/pélog & $1=\mathrm{T}$ \\
\hline & & Sindén & $3-8,11-16$ & Saléndro/pélog & $1=\mathrm{T}$ \\
\hline \multirow{2}{*}{\multicolumn{2}{|c|}{ 9. Kastawa }} & Alok & $1-4,13,17-19,29$ & Saléndro & $1=\mathrm{T}$ \\
\hline & & Sindén & $5-12,14-16,20-28,30-32$ & Saléndro & $1=\mathrm{T}$ \\
\hline \multirow{2}{*}{\multicolumn{2}{|c|}{ 10. Karawitan }} & Alok & $1-2,7-8,11$ & Pélog jawar & $1=\mathrm{T}$ \\
\hline & & Sindén & $3-6,9-10,12-14$ & Pélog jawar & $1=\mathrm{T}$ \\
\hline \multirow{2}{*}{\multicolumn{2}{|c|}{ 11. Kawitan $A$}} & Alok & $1-2,5-6,9,13-14$ & Saléndro & $1=\mathrm{T}$ \\
\hline & & Sindén & $3-4,7-8,10-12,15-20$ & Saléndro & $1=\mathrm{T}$ \\
\hline \multirow{5}{*}{\multicolumn{2}{|c|}{ 12. Kawitan $B$}} & Alok & $1-2$ & Madenda & $4=T$ \\
\hline & & & $5-6,9,13-14$ & Madenda & $4=P$ \\
\hline & & Sindén & $3-4,17$ & Madenda & $4=P$ \\
\hline & & & $7-8,15-16,18-20$ & Madenda & $4=T$ \\
\hline & & & $10-12$ & Madenda & $4=S$ \\
\hline \multirow{2}{*}{\multicolumn{2}{|c|}{ 13. Kéndo }} & Alok & $1-4,9,17-20,25$ & Pélog jawar & $1=\mathrm{T}$ \\
\hline & & Sindén & $5-8,10-16,21-24,26-32$ & Pélog jawar & $1=\mathrm{T}$ \\
\hline \multirow{2}{*}{\multicolumn{2}{|c|}{ 14. Puspa Warna }} & Alok & $1-2$ & Saléndro & $1=\mathrm{T}$ \\
\hline & & Sindén & $3-11$ & Saléndro & $1=\mathrm{T}$ \\
\hline \multirow{2}{*}{\multicolumn{2}{|c|}{ 15. Sétra Sari }} & Alok & $1-4,9-12$ & Pélog jawar & $1=\mathrm{T}$ \\
\hline & & Sindén & $5-8,13-20$ & Pélog jawar & $1=\mathrm{T}$ \\
\hline
\end{tabular}

Tabel 2. Penggunaan Laras dan Surupan pada Kawih Kepesindénan lagu Gedé 


\begin{tabular}{|c|c|c|c|c|c|c|c|}
\hline No. & Nama Lagu & Laras & Embat & Pangkat & Pancer & Kenong & Goong \\
\hline \multirow{6}{*}{\multicolumn{2}{|c|}{ 1. Banjar Mati }} & Saléndro & $2 \mathrm{w}$ & 4 & 1 & 4,4 & 4 \\
\hline & & & & & & 3,4 & 4 \\
\hline & & & $8 \mathrm{w}$ & & $4,3,1$ & $1,4,1,4$ & \\
\hline & & & & & & $1,3,1,4$ & 4 \\
\hline & & & $2 \mathrm{w}$ & & 1 & 4,4 & 4 \\
\hline & & & & & & 3,4 & 4 \\
\hline \multirow{3}{*}{\multicolumn{2}{|c|}{ 2. Barong }} & Pélog & $11 \mathrm{w}$ & 2 & 5,1 & $5,4,2,2$ & \\
\hline & & & & & $2,3-$ & $5,4,2,5$ & \\
\hline & & & & & 4 & $5,4,2$ & 2 \\
\hline \multirow{7}{*}{\multicolumn{2}{|c|}{ 3. Bayeman }} & Pélog jawar & 4 & 2 & $2,3-, 1$ & $3-, 2,1,5$ & 5 \\
\hline & & & & & 5,4 & $4,5,3-, 2$ & 2 \\
\hline & & & 8 & & 2,5 & $4,5,3-, 2$ & \\
\hline & & & & & & $3-, 2,4,5$ & 5 \\
\hline & & & 4 & & 2,5 & $4,5,3-, 2$ & 2 \\
\hline & & & 2 & & 2,5 & $4,52 \mathrm{x}$ & $52 x$ \\
\hline & & & & & & $3-, 22 x$ & $22 x$ \\
\hline \multirow{4}{*}{\multicolumn{2}{|c|}{ 4. Gagak Sétra }} & Pélog jawar & 8 & 2 & $4,5,2$ & $5,2,5,5,5,5$ & \\
\hline & & & & & & 4,2 & 2 \\
\hline & & & 2 & & 5 & 2,3 & 3 \\
\hline & & & & & 4 & 5,2 & 2 \\
\hline & Gorompol & Saléndro & 6 & 2 & 4,3 & $3,2,1,5,1,2$ & 2 \\
\hline \multirow{2}{*}{\multicolumn{2}{|c|}{ 6. Gunung Sari }} & Saléndro & 8 & 1 & $1,3,2$ & $4,3,4,5,4,3$ & \\
\hline & & & & & & $\begin{array}{l}5,1 \\
\end{array}$ & 1 \\
\hline \multicolumn{2}{|c|}{ 7. Karawitan } & Pélog jawar & 8 & 2 & $5,4,2,3$ & $1,1,1,4,2,3$ & \\
\hline \multirow{2}{*}{\multicolumn{2}{|c|}{ 8. Kastawa }} & Saléndro & 8 & 2 & $5,2,1,4$ & $5,5,5,2,1,1$ & 2 \\
\hline & & & & & & 5,2 & 2 \\
\hline \multirow{2}{*}{\multicolumn{2}{|c|}{ 9. Kawitan }} & Saléndro & 10 & 2 & $4,1,2,3$ & $\begin{array}{l}4,5,4,2,4,2 \\
4,4,1,5,1,4\end{array}$ & \\
\hline & & & & & & $1,3,4$ & 4 \\
\hline \multirow{2}{*}{\multicolumn{2}{|c|}{ 10. Kéndo }} & Pélog & 8 & 4 & $4,5,1$ & $3,4,5,1,5,3$ & \\
\hline & & & & & & 3,1 & 1 \\
\hline 11. & Puspawarna & Saléndro & 5 & 2 & $2,5,1,4$ & $3,5,5,5,2$ & 2 \\
\hline \multirow{2}{*}{\multicolumn{2}{|c|}{ 12. Sétrasari }} & Pélog jawar & 10 & 1 & $4,3,5,1$ & $5,1,5,1,3,1$ & \\
\hline & & & & & & $5,5,4,1$ & 1 \\
\hline \multirow{6}{*}{\multicolumn{2}{|c|}{ 13. Sungsang }} & Saléndro & $\begin{array}{l}2 \\
8\end{array}$ & 2 & $\begin{array}{c}2 \\
4.12\end{array}$ & $\begin{array}{c}3,3 \\
3,14.4\end{array}$ & 3 \\
\hline & & & & & & $\begin{array}{c}1,2 \\
1,1\end{array}$ & 2 \\
\hline & & & 2 & & $3,1,4$ & 2,3 & 3 \\
\hline & & & & & & 4,4 & 4 \\
\hline & & & 2 & & $2,1,3$ & 2,1 & 1 \\
\hline & & & & & & 2,2 & 2 \\
\hline \multirow{3}{*}{\multicolumn{2}{|c|}{ 14. Balagan Jur }} & Saléndro & 4 & 4 & $5,3,4$ & $4,1,1,4$ & 4 \\
\hline & & & & & & $4,1,3,4$ & 4 \\
\hline & & & & & & $4,3,1,4$ & 4 \\
\hline \multirow{2}{*}{\multicolumn{2}{|c|}{ 15. Banjar Jumut }} & Saléndro & 4 & 1 & 5,2 & $1,3,1,4$ & 4 \\
\hline & & & & & & $4,2,1,1$ & 1 \\
\hline \multirow{3}{*}{\multicolumn{2}{|c|}{ 16. Banjar Sari }} & Saléndro & 4 & 3 & 2 & $3,3,4,4$ & 4 \\
\hline & & & & & & $4,3,1,1$ & 1 \\
\hline & & & & & & $1,1,4,3$ & 3 \\
\hline \multirow{3}{*}{\multicolumn{2}{|c|}{ 17. Banjar Sinom }} & Saléndro & 4 & 3 & 2 & $3,1,4,4$ & 4 \\
\hline & & & & & & $\begin{array}{l}4,3,4,1 \\
1,4,3\end{array}$ & $\begin{array}{l}1 \\
3\end{array}$ \\
\hline & & & & & & $1,4,5,3$ & 3 \\
\hline
\end{tabular}


Karanginan, Karatonan, dan Kulu-Kulu Bem. Lagu gedé bentuk embat dalapan (8) wilet: Gunung Sari, Karawitan, Kastawa, dan Kéndo; Lagu gedé yang menggunakan embat khusus lima (5) wilet, genep (6) wilet, atau sapuluh (10) wilet: Puspawarna (5 wilet), Gorompol (6 wilet), Sétrasari (10 wilet), dan Kawitan (10 wilet); Lagu gedé dua bentuk embat: Balaganjur (wilet 2,8,2), Gagak Sétra (wilet 8 dan 2), Sungsang (wilet 2, 8,2,2); Lagu gedé tiga bentuk embat: Bayeman (wilet 4,8,4, dan 2) (Tabel 3).

\section{Kenongan dan Goongan}

Kenongan dan goongan memiliki kedudukan penting di dalam lagu gedé. Ada empat fungsi musikal nada kenongan dan nada goongan dalam garap lagu gedé yaitu sebagai penciri musikal gending atau lagu gede yang ditunjukkan dengan nada akhir di tiap baris lagu; sumber kreativitas garap musikal bagi seluruh pendukung; inspirasi penciptaan lagu atau gending baru; dan patokan nada untuk dilanjutkan, atau dalam istilah karawitan Sunda disebut "naékeun", kepada lagu berembat pendek (dua wilet), dengan nada kenongan dan goongan yang sama. Hasil identifikasi kenongan dan goongan terhadap lagu gedé ditemukan bahwa gending lagu gedé (lalamba dan lenyepan) ini umumnya memiliki pola gending tersendiri. Artinya, di setiap lagu gedé yang penulis temukan dalam beberapa embat lalamba ternyata sebagian besar lagu tidak ada yang sama pola nada kenongan dan goongan-

\begin{tabular}{|c|c|c|c|c|c|}
\hline No. & Nama Lagu & Jumlah Kenongan & Jumlah Goongan & Nada Kenongan & Nada Goongan \\
\hline 1. & Bayeman & 25 & 8 & 5,2 & 5,2 \\
\hline 2. & Sungsang & 18 & 6 & $3,1,2,4$ & $3,2,4,1$ \\
\hline 3. & Banjar Mati & 16 & 5 & $4,3,1$ & 4 \\
\hline 4. & Kawitan & 15 & 1 & $4,5,1,2,3$ & 4 \\
\hline 5. & Gagak Setra & 12 & 3 & $5,2,3,4$ & 2,3 \\
\hline 6. & Barong & 11 & 1 & $5,4,2$ & 2 \\
\hline 7. & Sétra Sari & 10 & 1 & $5,1,3,4$ & 1 \\
\hline 8. & Gunung Sari & 8 & 1 & $4,3,5,1$ & 1 \\
\hline 9. & Kastawa & 8 & 1 & $5,2,1$ & 2 \\
\hline 10. & Kéndo & 8 & 1 & $3,4,5,1$ & 1 \\
\hline 11. & Gorompol & 6 & 1 & $3,2,5,1$ & 2 \\
\hline 12 . & Panghudang Rasa & 16 & 4 & $4,2,1,3$ & 1,4 \\
\hline 13. & Tablo & 8 & 2 & 4,1 & 4 \\
\hline 14. & Tablo Kasmaran & 16 & 4 & 4,1 & 4 \\
\hline 15 . & Udan Mas & 10 & 3 & $1,4,2,3$ & $2,4,3$ \\
\hline 16. & Balaganjur & 12 & 3 & $4,1,3$ & 4 \\
\hline 17. & Banjar Sari & 12 & 3 & $4,3,1$ & $4,1,3$ \\
\hline 18. & Banjar Sinom & 12 & 3 & $3,1,4$ & $4,1,3$ \\
\hline 19. & Panglayungan & 12 & 3 & $1,3,4$ & $1,3,4$ \\
\hline 20. & Rénggong Bandung & 12 & 3 & $2,4,1$ & $2,4,1$ \\
\hline 21. & Rénggong Cimandé & 12 & 3 & $2,4,1$ & $2,4,1$ \\
\hline
\end{tabular}

Tabel 4. Nada Kenongan dan Nada Goongan dalam Lagu Gedé kepesindénan 
nya. Namun, di dalam lagu gedé embat lenyepan terdapat empat lagu yang menggunakan pola nada kenongan dan goongan yang sama, yaitu lagu Rénggong Bandung sama dengan lagu Rénggong Cimandé dan lagu Tablo sama dengan lagu Tablo
Kasmaran. Kesamaan ini dapat dimungkinkan terjadi karena dua fungsi kenongan dan goongan adalah menjadi sumber kreativitas dan inspirasi pemunculan gending baru seperti yang terjadi pada lagu Tablo menjadi lagu Tablo Kasmaran.

\begin{tabular}{|c|c|c|c|c|c|c|c|}
\hline Lagu & $E m$ & Kngn. & $G g$. & Lagu & $E m$. & Kngn. & Ggn. \\
\hline 1. Gorompol & 6 & $\begin{array}{l}3,2,1 \\
5,1,2\end{array}$ & 2 & Gegot & 2 & $\begin{array}{l}5,4,4,5 \\
5,2,2,5 \\
2,3,3,2\end{array}$ & $\begin{array}{l}5 \\
5 \\
2\end{array}$ \\
\hline 2. Gunung Sari & 8 & $\begin{array}{l}4,3,4,5 \\
4,3,5,1\end{array}$ & 1 & Rancag & & $\begin{array}{l}3,4 \\
3,1\end{array}$ & $\begin{array}{l}4 \\
1\end{array}$ \\
\hline 3. Kastawa & 8 & $\begin{array}{l}5,5,5,2 \\
1,1,5,2\end{array}$ & 2 & Bungur & 2 & $\begin{array}{l}4,5 \\
4,2\end{array}$ & $\begin{array}{l}5 \\
2\end{array}$ \\
\hline 4. Kawitan & 10 & $\begin{array}{c}4,4,1,5 \\
1,4,1,2 \\
4,4\end{array}$ & 2 & Badaya & & $\begin{array}{l}4,2 \\
4,4 \\
1,1\end{array}$ & $\begin{array}{l}2 \\
4 \\
1\end{array}$ \\
\hline 5. Setrasari & 4 & $\begin{array}{c}5,1,5,1 \\
3,1,5,5 \\
4,1\end{array}$ & 1 & Lampuyangan & 2 & $4,5,4,1$ & 1 \\
\hline 6. Balaganjur & 4 & $\begin{array}{l}4,1,1,4 \\
4,1,3,4 \\
4,3,1,3\end{array}$ & $\begin{array}{l}4 \\
4 \\
4\end{array}$ & Gendu & 2 & $5,1,5,4$ & 4 \\
\hline 7. Banjar Jumut & 4 & $\begin{array}{l}1,3,1,4 \\
4,2,1,1\end{array}$ & $\begin{array}{l}4 \\
1\end{array}$ & Kulu-kulu Barang & 2 & $2,4,2,1$ & 1 \\
\hline 8. Banjar Sari & 4 & $\begin{array}{l}3,3,4,4 \\
4,3,1,1 \\
1,1,4,3\end{array}$ & $\begin{array}{l}4 \\
3 \\
1\end{array}$ & Sinyur & 2 & $\begin{array}{l}2,1,2,3 \\
2,1,2,4\end{array}$ & $\begin{array}{l}3 \\
4\end{array}$ \\
\hline 9. Banjar Sinom & 4 & $\begin{array}{c}3,1,4,4 \\
4,3,4,1 \\
1,4,3,3\end{array}$ & $\begin{array}{l}4 \\
1 \\
3\end{array}$ & Rancag & 2 & $3,4,3,1$ & 4,1 \\
\hline 10. Jalantir & 4 & $1,5,1,1$ & 1 & Sorong Dayung & 2 & $2,3,2,1$ & 1 \\
\hline 11. Karang Ngambang & 4 & $\begin{array}{l}5,5,1,2 \\
2,2,3,5\end{array}$ & $\begin{array}{l}2 \\
5\end{array}$ & Catrik & 2 & $1,2,1,5$ & 5 \\
\hline 12. Karatonan & 4 & $\begin{array}{l}4,3,4,4 \\
4,2,4,1\end{array}$ & $\begin{array}{l}4 \\
1\end{array}$ & Gendu & 2 & $5,1,5,4$ & 4 \\
\hline 13. Kulu-kulu Bem & 4 & $1,4,2,4$ & 4 & Kulu-kulu Gancang & 2 & $5,2,5,4$ & 4 \\
\hline 14. Kuwung-kuwung & 4 & $2,5,1,2$ & 2 & Kulu-kulu Barang & 2 & $2,4,2,1$ & 1 \\
\hline 15. Lara-lara & 4 & $1,1,2,4$ & 4,1 & Kulu-kulu Barang & 2 & $2,4,2,1$ & 1 \\
\hline 16. Paksi Tuwung & 4 & $1,1,4,1$ & 1 & Kulu-kulu Barang & 2 & $2,4,2,1$ & 1 \\
\hline 17. Panglayungan & 4 & $\begin{array}{l}4,3,4,1 \\
1,1,4,3 \\
3,3,4,4\end{array}$ & $\begin{array}{l}1 \\
3 \\
4\end{array}$ & Rancag & 2 & $3,4,3,1$ & 4,1 \\
\hline 18. Pangrawit & 4 & $1,4,3,1$ & 1 & Kulu-kulu Barang & 2 & $2,4,2,1$ & 1 \\
\hline 19. Papalayon Ciamis & 4 & $\begin{array}{l}2,2,4,4 \\
4,4,2,2\end{array}$ & $\begin{array}{l}4 \\
2\end{array}$ & Samarangan Bem & & $\begin{array}{l}2,2,2,4 \\
4,4,3,2\end{array}$ & 4,2 \\
\hline 20. Parujakan & 4 & $1,5+, 1,1$ & 1 & Rancag & 2 & $3,4,3,1$ & 4,1 \\
\hline
\end{tabular}

Tabel 5. Lagu Gedé naék lagu Pasangannya 


\section{Pasangan Lagu Gedé}

Penyajian Lagu gedé pada Kiliningan, baik embat lalamba maupun embat lenyepan umumnya selalu menampilkan dua buah lagu, yaitu satu buah lagu gedé kemudian di taékeun/naékeun (diteruskan) pada salah satu lagu jalan yang berembat dua wilet sebagai lagu pasangannya. Adapun penempatan pasangan lagu gedé dan lagu jalan ini didasari atas kesamaan pola kenongan dan goongan, terutama pada kesamaan goongan, pangkat lagu, dan juga memiliki kesamaan masing-masing dalam tema lagu.

Lagu gedé memiliki peranan khusus dalam penyajian kiliningan yaitu hanya penyajian total musikal gending dan sekar (vokal), sehingga sangat umum terjadi pemberlakuan prinsip pasangan dalam penyajiannya. Namun, prinsipnya pasangan ini tidak selalu berlaku untuk penyajian lagu gedé di dalam pertunjukan wayang golék. Lagu gedé tidak harus ditampilkan sepasang dengan lagu pasangannya, karena penyajiannya sangat bergantung kepada kehendak dan otoritas dalang. Peran musikal lagu gedé dalam wayang golék pun berbeda, sebagai musik yang terikat dengan tarian wayang, murwa (nyanyian dalang), ilustrasi musikal adegan wayang, dan sajian hiburan dalam wayang.

Hal yang membedakan antara garap lagu gedé dalam kiliningan dan garap lagu gedé dalam wayang golék, yaitu: (a) Pangkat lagu dalam kiliningan umumnya dilakukan oleh pengrebab, sedangkan dalam wayang golék selalu diawali dengan pangkat tabuhan oleh pemain saron; (b) Struktur sajian lagu gedé dalam kiliningan berlangsung secara utuh, sedangkan pada wayang golék, struktur tersebut bisa berubah sesuai dengan kebutuhan adegan; (c) Pola ritmis lagu gedé dalam kiliningan berlangsung secara stabil (bertempo ajeg). Sedangkan dalam wayang golék menggunakan pola ritmis yang variatif disesuaikan dengan gerak tarian tokoh wayang (naik turun atau cepat lambat).

\section{Hubungan Interaksi Garap Musikal Karawitan}

Di balik penyajian musik yang terdengar, proses menghadirkan, menyusun, dan menyajikan lagu ini cukup rumit. Kerumitan dimaksud tidak hanya berhubungan dengan modal kemampuan musikal secara pribadi, tetapi juga berhubungan dengan kemampuan antar pemusik yang saling berinteraksi demi mewujudkan satu kepaduan dan keselarasan lagu, termasuk kemampuan saling menyadari setiap peran musikal memainkan lagu sehingga dibutuhkan kompetensi musikal yang mumpuni. Kemampuan teknis dasar musik harus sudah dilewati, sebab kebutuhan pertunjukan lebih kepada kemahiran setiap seniman menafsir musik dan saling bekerjasama membangun musik tersebut. Dalam lagu gedé semua pendukung pertunjukan ini memiliki kesetaraan peran musikal. Artinya, setiap peran kehadirannya dalam menampilkan lagu gedé sangat penting, bukan sebagai pelengkap.

Hubungan interaksi musikal antara pendukung penyajian lagu gedé ini terjadi karena kedudukan lagu sebagai melodi dasar terbuka untuk ditafsir oleh para sindén, alok, juru rebab, juru gambang, dan juru kendang. Penafsiran garap musikal ini sangat bergantung pada kemampuan musikal para pendukung penyaji lagu gedé. Apabila kemampuan musikal pangrawit mumpuni, maka proses menafsir garap itu dapat melahirkan gaya-gaya pribadi, seperti sinden dan alok yang melahirkan sénggol-sénggol, atau juga juru rebab, juru gambang, juru kendang yang melahirkan gaya kekhasan tabuhan secara pribadi.

Demikian pula hubungan antara kompetensi musikal pemain dan interaksi musikal yang dijalin oleh dan antar pemain, memberi ruang kehadiran teknik-teknik senggol, gésékan rebab, tabuhan gambang, dan tepakan kendang yang digunakan dalam lagu gedé kepesindénan. Nama-nama teknik sénggol tersebut, antara lain: galantang pondok, galantang panjang, geter rékép, geter carang, sorodot, solédat, giwar, gebés/gebeg, koléang, lageday, kerejet, eundeuk, dan ngayun. Teknik gésékan rebab dan gambang disesuaikan dengan peran musikalnya, antara lain: teknik mayunan, ngarangkén, nyarengan, dan negeskeun. Adapun untuk penamaan tepakan kendang lagu gedé umumnya pengendang pelaku menyebutnya teknik tepakan melem. Untuk lebih jelasnya lihat beberapa cuplikan contoh notasi sebagai berikut. 
Contoh notasi sénggol sindén

Sénggol galantang pondok

$\overline{\overline{44} \overline{44} \overline{44}}$

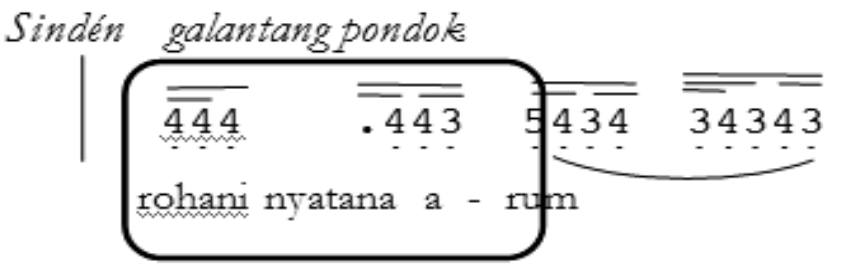

Contoh notasi garap interaksi musikal vokal sinden dan rebab

dalam lagu Kawitan Sinden Emi Hayati Laras Saléndro

Sindén

$\mid$
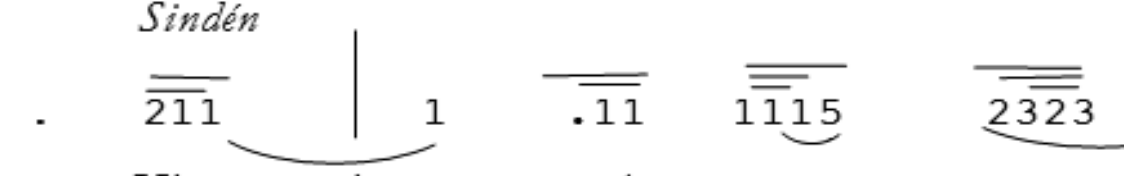

Kinan - ti pame - kar a - rum

Rebab ngarangken

negeskeun

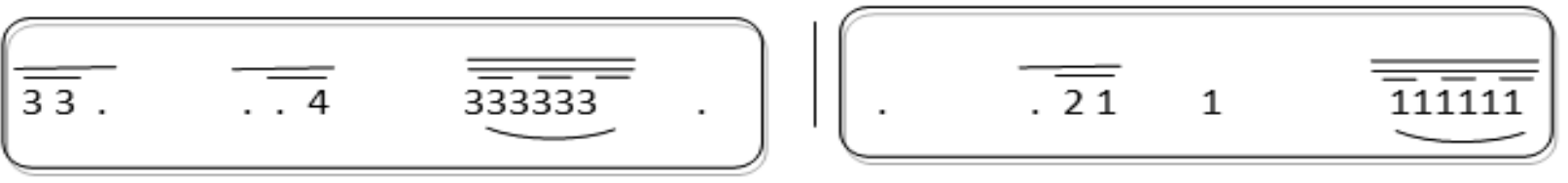

Contoh notasi garap interaksi musikal sinden dan alok
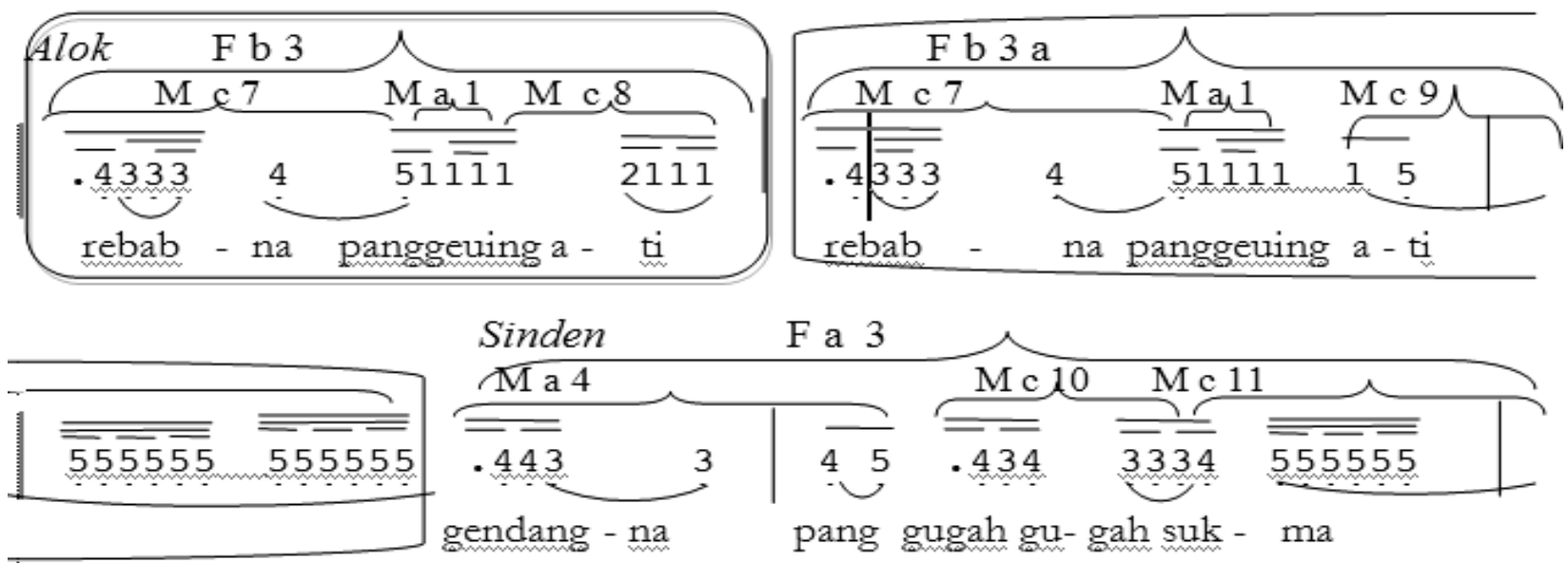

$\overbrace{\begin{array}{l}\text { Sinden } \\ \text { gendang - na }\end{array}}^{\text {Ma } 4}$

F a 3

Contoh notasi garap interaksi musikal vokal sinden dan gambang

\begin{tabular}{|c|c|c|c|c|c|c|c|c|c|c|c|c|}
\hline 111111 & ... $\overline{4}$ & & $5 \overline{12}$ & & $33 \overline{3}$ & 2 & $\overline{4}$ & $\overline{343}$ & 3 & 33 & & $\overline{333333}$ \\
\hline & Wa & $\mathrm{da}$ & laku & & ng per & & wi & & - & & $\mathrm{ra}$ & \\
\hline Mayunan & & & areng & & & & $\mathrm{Ngc}$ & zrang & kén & & & Mayunan \\
\hline$==$ & $=$ & & & & $=$ & $\overline{\overline{ }}$ & $=$ & 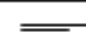 & $=$ & 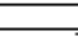 & & \\
\hline 44.455 & .5 & $1 i$ & . 1 & $2 \dot{3}$ & 34 & 32 & 32 & $\mathrm{ii}$ & .5 & 1 & 34 & 30303 \\
\hline$\overline{ }=\overline{=}$ & $=$ & $\overline{\overline{ }}$ & $=$ & $\overline{\overline{ }}$ & $\overline{=}$ & $\overline{\overline{ }}$ & $=$ & $\overline{\overline{ }}$ & $\overline{-}$ & $\overline{\overline{ }}$ & - & $\overline{10}$ \\
\hline $\begin{array}{lll}44 & 44 & 55\end{array}$ & 55 & 11 & 11 & 23 & 34 & 38 & .2 & 11 & 1 & 12 & 3. & 30303 \\
\hline
\end{tabular}


Contoh notasi garap interaksi musikal vokal sinden dan kendang

$$
\text { Sinden }
$$
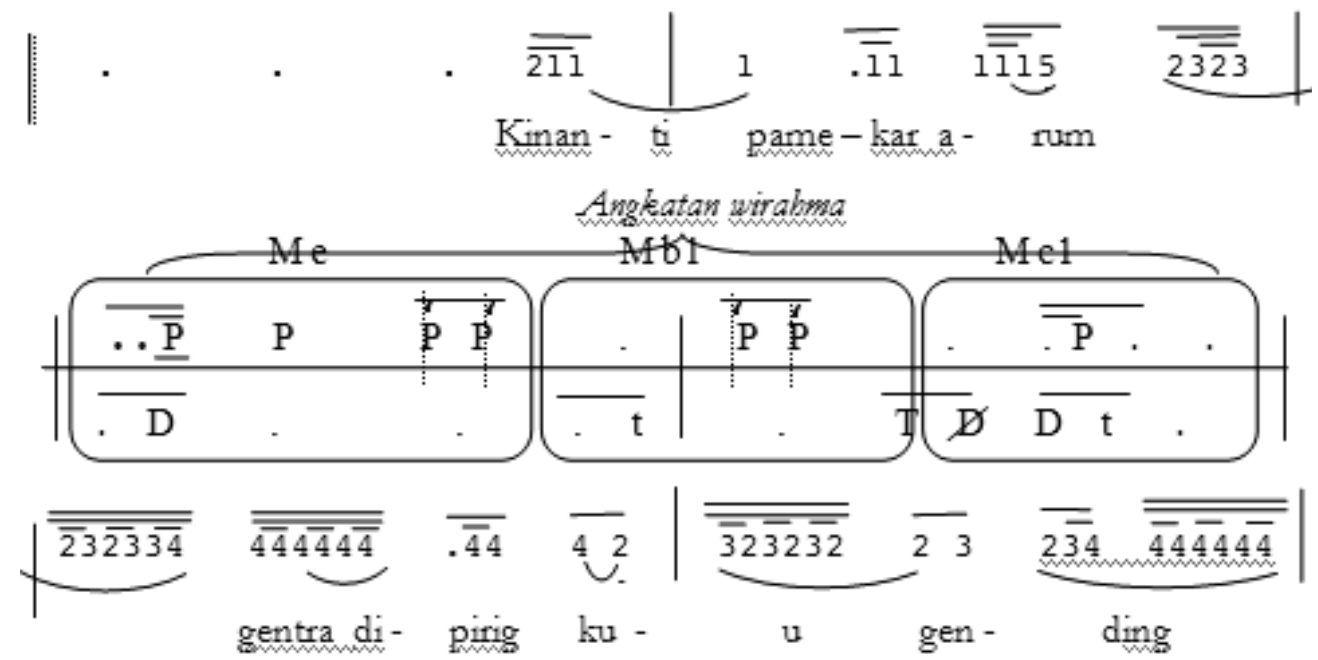

ngalaras

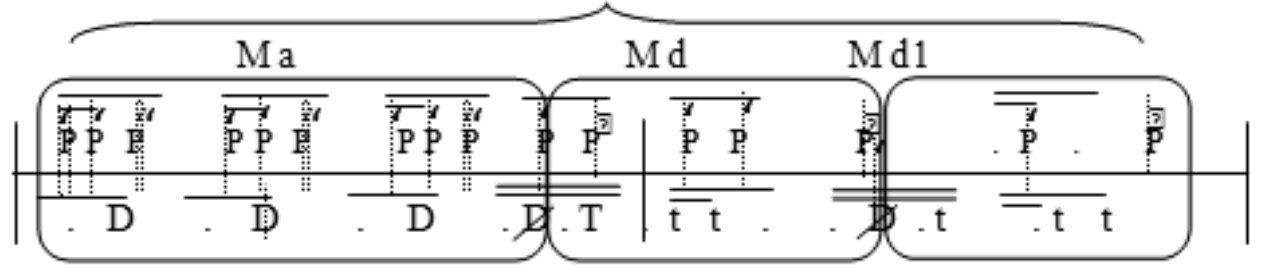

Contoh notasi gending dan lagu

\section{Kawitan}

\section{Laras Salkndro}

Embat: lalamba

Notasi: Endah Irawan

Pangiadi (matra 1-2)

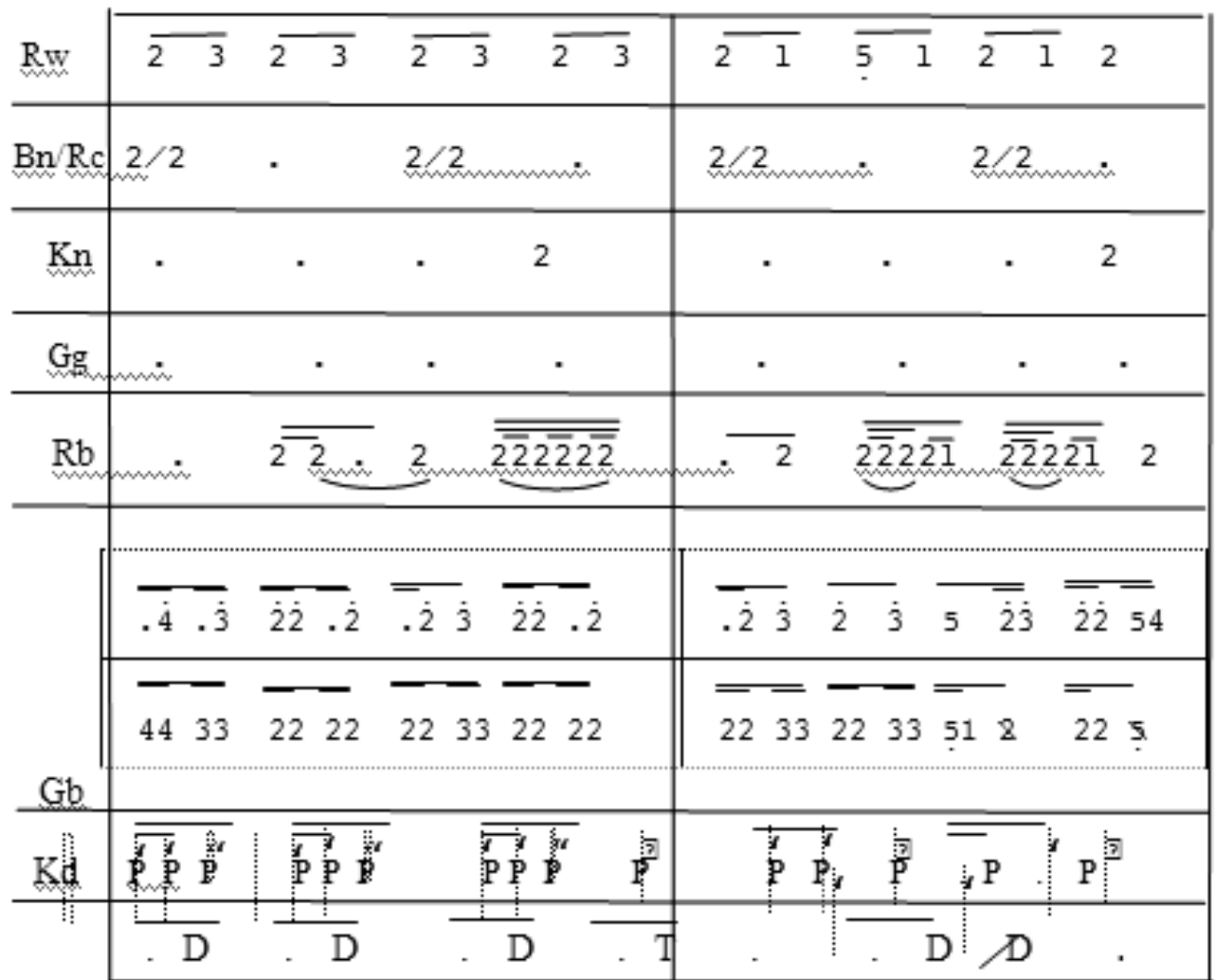


Pangjadi merupakan garapan gending sebelum masuk vokal, yang umumnya garap musikal sebanyak 1 kenongan ( 2 matralbar) atau 2 kenongan ( 4 matra/bar) yang penempatannya biasa di awal, tengah, dan setelah akhir lagu ketika mau mengulang lagu kembali. Matra merupakan istilah untuk penamaan garis birama atau bar dalam musik Barat. Rw singkatan dari rampak waditra, yang maksudnya instrument yang dimainkan terdiri dari sebagian instrumen gamelan, yaitu: saron 1, saron 2, peking, dan demung. Adapun singkatan namanama instrument yang lainnya: Sr 1 (saron 1), Sr2 (saron 2), $\mathrm{Pk}$ (peking), $\mathrm{Dm}$ (demung), $\mathrm{Bn}$ (boning), Rc (rincik), Kn (kenong), G (goong), Rb (rebab), $\mathrm{Gb}$ (gambang), dan singkatan S (sinden), A (alok).

Berdasarkan hasil analisis dari beberapa aspek di atas, keunggulan-keunggulan karakter musikal lagu gedé yang penulis temukan sebagai berikut. Pertama, laras dan surupan dalam lagu gedé merupakan persyaratan yang harus dikuasai bagi seorang sindén, alok, dan pemain rebab. Laras menjadi kerangka acuan sekaligus bingkai untuk menafsirkan sistem nada yang melekat atau relevan dengan lagu, gending atau pun iringan lagunya. Penguasaan surupan sangat menentukan kemampuan seorang vokalis (sindén dan alok) dan pemain rebab. Bila pengolahan surupan dilakukan secara kreatif dan cermat, maka gaya ungkap nyanyian pribadi sindén dan atau alok, maupun gaya ungkap rebaban pengrebab menjadi nampak. Artinya, surupan maupun laras menjadi alat atau teknik untuk mengungkapkan ekspresi musikalitasnya. Hasil identifikasi laras terhadap 52 lagu gedé kepesindénan yang dikaji terdapat empat jenis laras saléndro, pélog, madenda, dan degung. Keempat jenis laras dimaksud dapat disajikan secara mandiri satu laras maupun dalam cara penggabungan dua atau tiga laras. Ada 13 lagu laras saléndro: 12 lagu laras pélog: 11 lagu laras madenda: 1 lagu laras degung: 3 lagu gabungan laras saléndro dan madenda: 4 lagu gabungan laras madenda dan degung: dan 1 lagu gabungan laras saléndro, madenda dan degung: Tablo Kasmaran.

Kedua, embat dapat juga berarti wilet, yaitu penentuan ukuran waktu tentang cepat lambatnya perjalanan musikal, atau periode struktural berdasarkan aksentuasi melodi yang diletakkan pada bagian garapan melodi dan ditandai dengan nada pancer, kenong, dan gong. Penggunaan embat dalam lagu gedé terbagi dalam dua pola irama lagu, yaitu lenyepan dan lalamba. Embat lagu gedé irama lenyepan umumnya adalah embat opat (4) wilet. Dalam irama lalamba terdiri atas beberapa pola embat, antara lain: lima (5) wilet, genep (6) wilet, dalapan (8) wilet, dan sapuluh (10) wilet. Hasil identifikasi embat lagu gedé menunjukan Lagu gedé bentuk embat 4 wilet: Balaganjur, Banjar Jumut, dan yang lainnya; embat dalapan (8) wilet: Gunung Sari, Karawitan, Kastawa, embat khusus sapulub (10) wilet: Setra sari dan Kawitan; (5 wilet) Puspawarna; (6 wilet) Gorompol; Lagu gedé dua bentuk embat: Balaganjur (wilet 2,8,2), Gagak Sétra (wilet 8 dan 2), Sungsang (wilet 2,8,2,2); Lagu gedé tiga bentuk embat: Bayeman (wilet 4,8,4, dan 2).

Ketiga, kenongan dan goongan memiliki kedudukan penting di dalam lagu gedé. Sekurangnya ada empat fungsi musikal nada kenongan dan nada goongan dalam garap lagu gedé, antara lain sebagai: penciri musikal gending atau lagu gede yang ditunjukkan dengan nada akhir di tiap baris lagu; sumber kreativitas garap musikal bagi seluruh pendukung; inspirasi penciptaan lagu atau gending baru; dan patokan nada untuk dilanjutkan, atau dalam istilah karawitan Sunda disebut "naékeun”, kepada lagu berembat pendek (dua wilet), dengan nada kenongan dan goongan yang sama. Hasil identifikasi kenongan dan goongan terhadap lagu gedé ditemukan bahwa gending lagu gedé (lalamba dan lenyepan) umumnya memiliki pola gending tersendiri. Artinya, di setiap lagu gedé yang penulis temukan dalam beberapa embat lalamba ternyata sebagian besar lagu tidak ada yang sama pola nada kenongan dan goongan-nya. Kecuali di dalam lagu gedé embat lenyepan terdapat empat lagu yang menggunakan pola nada kenongan dan nada goongan yang sama, yaitu lagu Rénggong Bandung sama dengan lagu Rénggong Cimandé dan lagu Tablo sama dengan lagu Tablo Kasmaran.

Keempat, penyajian lagu gedé pada kiliningan, baik embat lalamba maupun embat lenyepan umumnya selalu menampilkan dua buah lagu, yaitu satu buah lagu gedé kemudian di taékeun/naékeun (diteruskan) pada salah satu lagu jalan yang berembat dua wilet sebagai lagu pasangannya. Dalam 
penyajian kiliningan, lagu gedé memiliki peranan khusus yaitu hanya penyajian total musikal gending dan sekar (vokal), sehingga sangat umum terjadi pemberlakuan prinsip pasangan dalam penyajiannya. Namun prinsip pasangan ini tidak selalu berlaku untuk penyajian lagu gedé di dalam pertunjukan wayang golék, karena peran musikal terikat dengan tarian wayang, murwa (nyanyian dalang), ilustrasi musikal adegan wayang, dan sajian hiburan dalam wayang golek. Hal yang membedakan antara garap lagu gedé dalam kiliningan dan garap lagu gedé dalam wayang golék, yaitu: Pangkat lagu dalam kiliningan umumnya dilakukan oleh pengrebab, sedangkan dalam wayang golék selalu diawali dengan pangkat tabuhan oleh pemain saron; Struktur sajian lagu gedé dalam kiliningan berlangsung secara utuh. Dalam wayang golék, struktur tersebut bisa berubah sesuai dengan kebutuhan adegan; Pola ritmis lagu gedé dalam kiliningan berlangsung secara stabil (bertempo ajeg). Sedangkan dalam wayang golék menggunakan pola ritmis yang variatif disesuaikan dengan gerak tarian tokoh wayang (naik turun atau cepat lambat).

Kelima, dalam lagu gedé semua pendukung pertunjukan ini memiliki kesetaraan peran musikal. Artinya, setiap peran kehadirannya dalam menampilkan lagu gedé sangat penting, bukan sebagai pelengkap. Hubungan interaksi musikal antara pendukung penyajian lagu gedé ini terjadi karena kedudukan lagu sebagai melodi dasar terbuka untuk ditafsir garap oleh para sindén, alok, juru rebab, juru gambang, dan juru kendang. Penafsiran garap musikal ini sangat bergantung pada kemampuan musikal para pendukung penyaji lagu gedé. Apabila kemampuan musikal pangrawit mumpuni, maka proses menafsir garap itu dapat melahirkan gaya-gaya pribadi, seperti sinden dan alok yang melahirkan sénggol-sénggol, atau juga juru rebab, juru gambang, juru kendang yang melahirkan gaya kekhasan tabuhan secara pribadi.

Hubungan antara kompetensi musikal pemain dan interaksi musikal yang dijalin oleh dan antar pemain memberi ruang kehadiran teknikteknik senggol, tabuhan rebab, tabuhan gambang, dan tepakan kendangyang digunakan dalam lagu gedé kepesindénan. Nama-nama teknik sénggol tersebut, antara lain: galantang pondok, galantang panjang, geter rékép, geter carang, sorodot, solédat, giwar, gebés/gebeg, koléang, lageday, kerejet, eundeuk, dan ngayun. Teknik tabuhan rebab dan gambang disesuaikan dengan peran musikalnya, antara lain: teknik mayunan, ngarangkén, nyarengan, dan negeskeun. Adapun untuk penamaan tepakan kendang lagu gedé umumnya pengendang pelaku menyebutnya teknik tepakan melem.

\section{Penutup}

Struktur lagu gedé kepesindénan memiliki kompleksitas musikal, tersusun dari unsur-unsur musik dan sastra yang menyatu. Unsur-unsur musik dimaksud meliputi: nada, laras, surupan, wilet, pola kenongan dan goongan, wirahma beserta prinsip naékeun-nurunkeun, juga hubungan garap di antara sindén, alok, rebab, gambang, dan kendang, atau dalang. Adapun garap sastra dalam lagu gedé terdapat beragam gaya dan aspek, antara lain: stilisasi bahasa dengan mempertimbangkan aspek syair yang murwakanti (persajakan bunyi), rineka wacana (diksi), rinéka sastra (gaya bahasa), dan pakeman basa (idiom).

Kehadiran lagu gedé menampilkan dimensi karawitan yang tidak sederhana. Tidak sekedar lagu yang dapat digurit (dicipta) atau dinyanyikan, tetapi dibutuhkan kepekaan dan kemahiran dari orang yang mencipta atau menyajikannya. Di dalam lagu ini, mutu kesenimanan yaitu teknik, gaya, dan ornamentasi dari pencipta dan penyaji dapat dicirikan dan diuji. Kreativitas garap lagu gedé dalam karawitan Sunda dapat menjadi barometer untuk menilai kualitas kesenimanan.

Era tahun 1950-an s.d. 1980-an merupakan masa populernya lagu gedé. Popularitasnya terjadi di dunia pertunjukan, pendidikan dan rekaman. Namun setelah tahun 1980-an, lagu gedé terpinggirkan oleh kesenian baru. Lagu gedé hanya bertahan pada pertunjukan wayang golék, itupun sudah jarang. Sekarang, kehadiran lagu gedé pada karawitan Sunda nyaris sudah langka. D e n ga n ketiadaan lagu gedé, mutu garap kesenimanan sinden dan pangrawit (penabuh gamelan) dan jalinan interaksi kemampuan musikal di antara pemeran garap yaitu vokal, rébab, gambang, dan kéndang mengalami keterbatasan serupa. Perkembangan 
terbaru, lagu gedé justru digunakan sebagai sumber kreativitas penggarapan kesenian tembang Sunda, degung, dan bajidoran/jaipongan.

\section{Kepustakaan}

Ardana, I Ketut. 2013. "Pengaruh Gamelan terhadap Baleganjur Semaradana" dalam Resital Jurnal Seni Pertunjukan, Volume 14. No. 2-Desember 2013: 141-152.

Hermawan, Deni. 2002. Etnomusikologi; Beberapa Permasalahan dalam Musik Sunda. Bandung: STSI Press.

Herdini, Heri. 2007. Raden Machjar Angga Koesoemadinata: Pemikiran dan Aktivitasnya dalam Karawitan Sunda. Bandung: Sunan Ambu Press

Irawan, Endah. 2003. "Komparasi Senggol Tiga Sinden Popular Jawa Barat: Hj. Idjah Hadijah, Cicih Cangkurileung dan Cucu Setiawati” [Tesis] Prodi Pengkajian Seni Pertunjukan dan Seni Rupa UGM.
Koesoemadinata, Rd. Machjar Angga. 1950. Ringkesan Pangawikan Rinenggaswara.

Djakarta: Noordhoff- kolff N. V. 1969. Ilmu Seni Raras. Djakarta: Pradnjaparamita.

Kunst, Jaap. 1973. Music In Java: Its History, Its Theory And Its Technique. Netherlands: Martinus Nijhoff.

Rustandi Mulyana, Aton. 2005. "Gurit Lagu Kawih Sunda". [Tesis] Program Pascasarjana Institut Seni Indonesia (ISI) Surakarta.

Scruton, Roger. 2009. The Aesthetics of Music. New York: Oxford. University Press.

Shils, Edward. 1987. Tradition. Chicago: The University of Chicago Press.

Supanggah, Rahayu. 2002. Bothekan Karawitan 1. Jakarta: MSPI. 2009. Bhotekan Karawitan II: Garap. Surakarta: ISI Press.

Wade, Bonnie C. 2004. Thinking Musically: Experiencing Music, Expressing Culture. New York: Oxford University Press. 